\title{
THE RESEARCH ON PHYSICAL EDUCATION TRAIT ANXIETY STATES OF STUDENTS IN MUCUR VOCATIONAL AND TECHNICAL EDUCATION CENTRE ${ }^{1}$
}

\section{MUCUR MESLEKI VE TEKNIK EĞITTIM MERKEZINDEKI ÖĞRENCİLERIN BEDEN EĞITTIMI SÜREKLİ KAYGI DURUMLARININ INCELENMESI}

\author{
Meryem ALTUN
}

Ömer Halisdemir University, School of Physical Education and Sports, Niğde / Turkey

Öz: Bu araştırmanın amacı; Mucur Mesleki ve Teknik Eğitim Merkezinde Öğrenim Gören Öğrencilerin Beden Eğitimi Sürekli Kaygı Durumlarını İncelemektir. Bu araştırmanın modeli, tarama modelidir. Araştırmaya, Kırșehir/Mucur Mesleki ve Teknik Eğitim Merkezinde 2015-2016 eğitim öğretim döneminde öğrenim gören 15-17 yaş arası 50 kız, 150 erkek olmak üzere toplam 200 öğrenci gönüllü olarak katılmıştır. Ölçme arac1; Varol (2014)'un Türk lise öğrencileri üzerinde geçerlilik güvenirlik çalışmasını yaptı̆ı̆ özgün formu "The Physical Education Trait Anxiety Scale" olan ölçek kullanılmıştır. Verilerin analizinde; SPSS 21 paket programı kullanılmıştır. Normal dağılım göstermeyen bu çalışmada cinsiyet değişkeni için Mann Whitney U, yaş değişkeni içinde Kruskal Wallis testleri kullanılmıştır. Araştırma sonucunda elde edilen bulgulara göre; cinsiyet değişkenine göre gruplar arasında Bilişsel, Somatik ve Endişe alt boyutlarında istatistiksel olarak anlamlı farklılık bulunmamıștır. Yaş değişkenine göre ise farklı yaş grupları arasında Bilişsel, Somatik ve Endişe alt boyutlarında anlamlı farklılık bulunmuştur. 15 yaşında olanların sıra ortalamaları en yüksek çıkmıştır. Ayrıca alt boyutlar arasında pozitif yönlü güçlü bir iliş̧i bulunmuştur. Sonuç olarak; cinsiyet arasında anlamlı farklılık bulunmazken yaş grupları arasında anlamlı farklılıkların olduğu tespit edilmiştir. 15 ile 17 yaş gruplarında bilişsel, somatik, endişe alt boyutlarında, 16 ile 17 yaş grupları arasında da endișe alt boyutunda anlamlı farklılığın olduğu söylenebilir.

Anahtar Kelimeler: Beden Eğitimi, Sürekli Kaygı
Abstrack: The purpose of this research is to examine Physical Education Trait Anxiety States of Students who are studying at Mucur Vocational and Technical Education Centre. The model of this research is the screening model. A total of 200 students, aged between 15 and 17, who were educated during the 2015-2016 education period at Kırșehir/Mucur Vocational and Technical Education Centre including 50 girls and 150 boys, have been voluntarily participated in the research. "The Physical Education Trait Anxiety Scale", which is the original form of the validity and reliability study of Varol (2014) on Turkish high school students, has been used as measuring tool. SPSS 21 package program is used in the analysis of data. Mann Whitney U for gender change and Kruskal Wallis test have been used in this study which does not a normal distribution for age variance According to findings obtained, there was no statistically significant difference in the Cognitive, Somatic and Anxiety sub-scales among the groups according to gender variable. According to the age variable, there was a meaningful difference in cognitive, somatic and anxiety sub-scales among different age groups. It has been found that the average age of 15-year-old is the highest. It has been also found that there is a strong positive correlation between sub-dimensions. It has been detected as a result that there are significant differences between the age groups while there is no significant difference between genders. It can be said that there is a significant difference in cognitive, somatic, anxiety sub-dimensions between 15 and 17 years age group and between 16 and 17 age groups in anxiety sub-dimension.

Key Words: Physical Education, Continuous Anxiety

Doi: 10.17363/SSTB.2017.1.003

(1) Corresponding Author: Meryem ALTUN, Ömer Halisdemir University, School of Physical Education and Sports, Niğde/Turkey, mrymltn@hotmail.com, Received: 17/12/2016, Revision date: 16/02/2017, Accepted: 21/03/2017 Type of article (Research) Conflict of Interest: None / "None of Ethics Committee" 


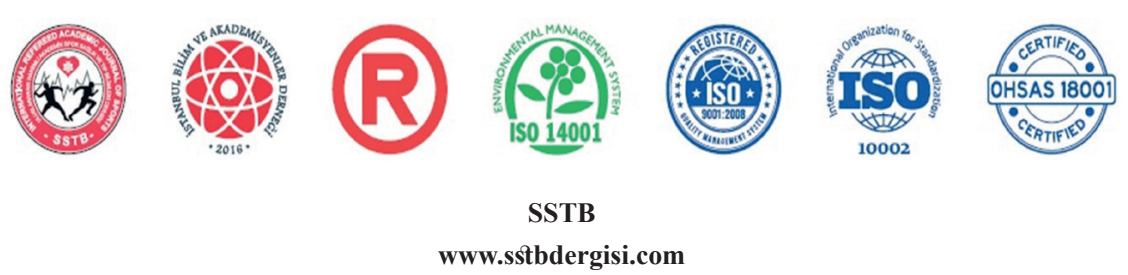

International Refereed Academic Journal of Sports, Health and Medical Sciences

January - February - March Issue 22 Winter Season Year: 2017

GEL CODE: I21-I129-M12- ID:329 K:327

ISSN Print: 2146-8508 Online 2147-1711

(ISO 18001-OH-0090-13001706 / ISO 14001-EM-0090-13001706 / ISO 9001-QM-0090-13001706 / ISO 10002-CM-0090-13001706) (TRADEMARK)

(2015/04315- 2015-GE-18972)

\section{INTRODUCTION}

Anxiety is expressed as a state of fear and tension under a threat. Spielberger (1972) describes the anxiety as unpleasant emotional and observable responses, such as sorrow, perception, and tension that create stressful states. Trait anxiety is expressed as a tendency to perceive specific states as threats and to increase the level of state concerns over these states (Spielberger, 1966, et al., Martens et al., 1990). Trait anxiety is the predisposition of the individual to anxiety. This may be referred to as the tendency to perceive states in which the person is usually stressed or to interpret them as stress (Öner and LeCompte, 1998).

According to psychologists, the years in which the individual feels the anxiety that are the somatic and mental indicators of perceptions against the emotional and physical states are the two years after birth and adolescence years (Kartopu, 2012: 147-170). Adolescence is the most turbulent period in which the level of anxiety has reached the highest level in human life. Intensity and instability, loneliness and tiredness, lack of confidence and anxiety state, adaptation problems in the environment and conflicts within the family can be seen in the emotions of children who are in this period. Examination anxiety, school and course anxiety, identity anxiety, parental attitudes and behaviours are important factors in ado- lescence 's anxiety factors (Bacanl1, 2005). According to the developmental periods, the anxiety level varies, and fluctuations in adolescence and anxiety levels can be seen from the kindergarten to adolescence (Duchesne et al., 2008: 1134-1146). The physical development of adolescents significantly affects their mental structures and behavioural characteristics during the middle and late adolescence periods (14-19 years) after the first adolescence period of 11-14 years (Tekindal et al., 2010: 79-93).

The behaviours also go wrong at the ratio of intensity of anxiety, which also affect the learning process (Phillips, 1984: 2000-2016), and lack of perception and attention problems occur (Kaya and Varol, 2004). Particularly, the trait anxiety state causes the failure of the course success together with lack of perception and attention problems in the individuals (Kapıkıran, 2006: 3-8). According to Kazelskis and Kazelskis (1999), while the cognitive dimension of anxiety consists due to the fact that person think his performance being small, the affective dimension consists of the reactions, tension and nervous emotions shown to the states encountered (Akt. Tekindal et al., 2010). In particular, the emotional dimension of the physical education course requires that the teacher must manage this course consciously (Bauman, 1994). The psychological preparations of the students are 


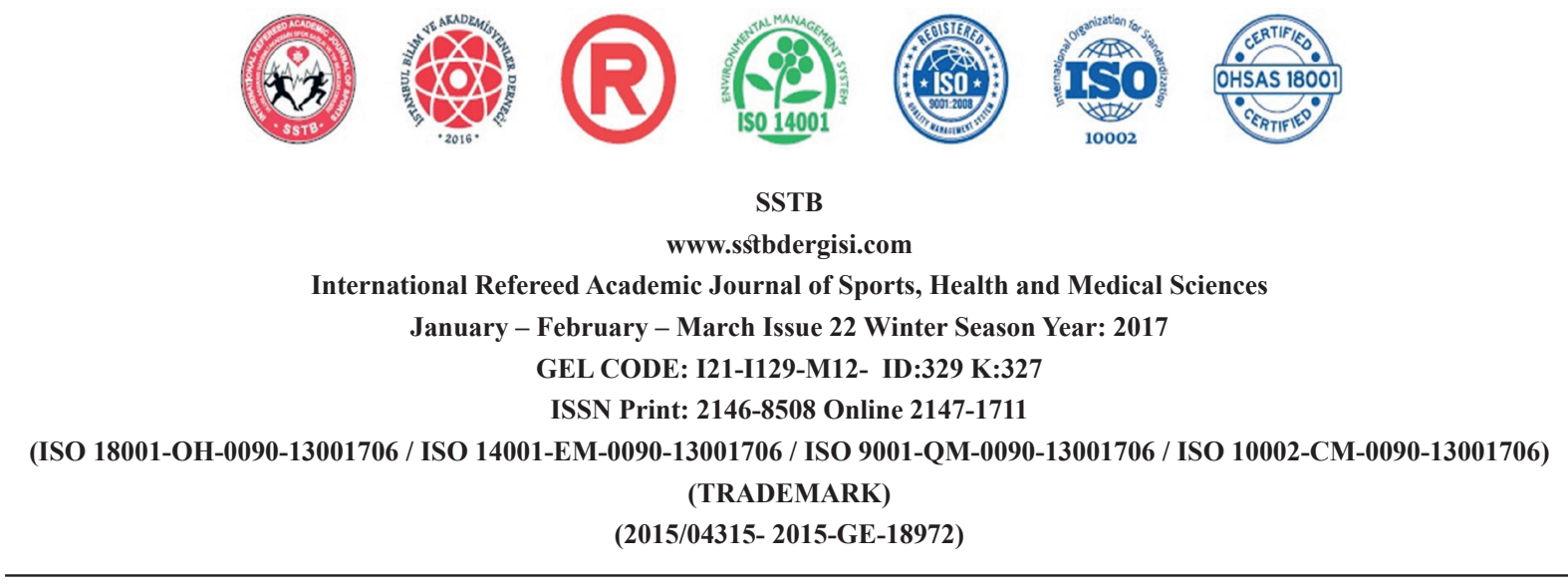

an important factor for the efficiency of course. The psychological states of the students and their performance are also closely related to their level of anxiety. One of the most popular courses of the students who are studying at every stage of education is Physical Education. In this direction, it has become a matter of curiosity whether there is a state of anxiety or not for the Physical Education course in the students. When studies and scales about physical education and sports anxiety are examined, it is seen that studies are generally related to anxiety levels of students or athletes or to racial anxiety.

\section{METHOD}

The model of this research is the screening model (Açışl1, 2016, Karaman, 2016: 273285). It is called as screening (survey) research aiming to collect data in order to determine specific characteristics of a group (Büyüköztürk, et al., 2012). It has been tried to describe an existing situation by dealing and without any change. A total of 200 students, aged between 15 and 17, who were educated during the 2015-2016 education period at Kırşehir/Mucur Vocational and Technical Education Centre including 50 girls and 150 boys, have been voluntarily participated in the research (Karataş et al, 2016: 109-118) As the school is a vocational technical high school, the number of female students is low.

\section{Data Collection Tools}

A validity reliability study has been conducted on Turkish high school students by Varol (2014) for the Physical Education Trait Anxiety Scale, which is the original form "The Physical Education Trait Anxiety Scale" and is developed by Barkoukis, Rodafinos, Koidou and Tsorbatzoudis (2012). The scale consists of 3 sub-dimensions and 18 articles in which 6 articles are included in each of "Cognitive Processes", "Somatic Anxiety" and "Anxiety". For the adaptation study, the original scale was firstly translated into Turkish. The scales were applied to a group of high school students at two-week intervals in order to determine whether the Turkish form and the English form had the same meaning in practice. To test the consistency between the scores from both scales, the Pearson Moments Multiplication Correlation Coefficient was calculated and it has been found to be .995. According to this, it is seen that there is a high positive correlation between English and Turkish scales. The scale ensured its linguistic equivalent was applied to 190 high school students in Aksaray. The Cronbach Alpha score of the scale was .94 and the test-retest reliability was .96 . The "cognitive processes" from the sub-scales were Cronbach Alpha value .93, "somatic manxiety" were .97 and anxiety sub-scales were .98. As a result of confirmatory factor analysis made 


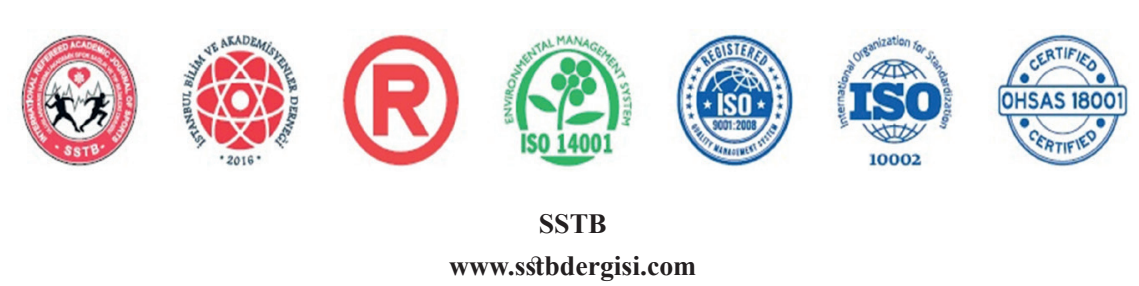

International Refereed Academic Journal of Sports, Health and Medical Sciences

January - February - March Issue 22 Winter Season Year: 2017

GEL CODE: I21-I129-M12- ID:329 K:327

ISSN Print: 2146-8508 Online 2147-1711

(ISO 18001-OH-0090-13001706 / ISO 14001-EM-0090-13001706 / ISO 9001-QM-0090-13001706 / ISO 10002-CM-0090-13001706) (TRADEMARK)

(2015/04315- 2015-GE-18972)

for validity, it has been determined that the distribution of the articles forming the scale is the same as the distribution in the original dimension. SPSS 21 package program is used in the analysis of data. Mann Whitney $U$ for gender change and Kruskal Wallis test have been used in this study which does not a normal distribution for age variance

\section{FINDINGS}

Table 1. Demographic Characteristics of Students

\begin{tabular}{llll}
\hline & & Frequency & Percentage $\%$ \\
\hline \multirow{3}{*}{ GENDER } & Male & 150 & 75.0 \\
\cline { 2 - 4 } & Female & 50 & 25.0 \\
\cline { 2 - 4 } & Total & 200 & 100,0 \\
\hline \multirow{3}{*}{ AGE } & 15 years & 100 & 50.0 \\
\cline { 2 - 4 } & 16 years & 51 & 25.5 \\
\cline { 2 - 4 } & 17 years & 49 & 24.5 \\
\cline { 2 - 4 } & Total & 200 & 100,0 \\
\hline
\end{tabular}

As seen in Table 1, 75.0\% of the students are male and $25 \%$ of the students are female. Since the school has vocational technical high school qualifications, the number of female students is low. $50,0 \%$ of the students is 15 years old, $25,5 \%$ are 16 years old and $24,5 \%$ are 17 years old. 


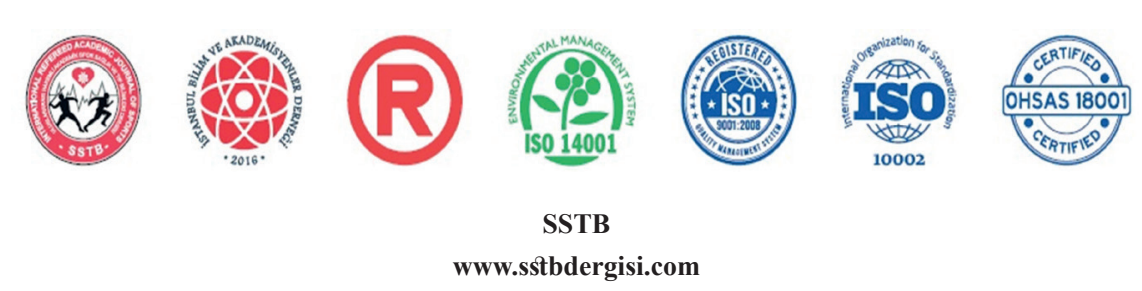

International Refereed Academic Journal of Sports, Health and Medical Sciences

January - February - March Issue 22 Winter Season Year: 2017

GEL CODE: I21-I129-M12- ID:329 K:327

ISSN Print: 2146-8508 Online 2147-1711

(ISO 18001-OH-0090-13001706 / ISO 14001-EM-0090-13001706 / ISO 9001-QM-0090-13001706 / ISO 10002-CM-0090-13001706)

(TRADEMARK)

(2015/04315- 2015-GE-18972)

Table 2. Mann Whitney U Test Results by Gender Variance

\begin{tabular}{|c|c|c|c|c|c|c|}
\hline Gender & & $\mathrm{N}$ & $\begin{array}{l}\text { Line Ave- } \\
\text { rage }\end{array}$ & Total Line & $\mathrm{U}$ & $\mathrm{P}$ \\
\hline \multirow{3}{*}{$\begin{array}{l}\text { Cognitive Pro- } \\
\text { cesses }\end{array}$} & Male & 150 & 103.19 & 15479.00 & 3346.00 &, 246 \\
\hline & Female & 50 & 92.42 & 4621.00 & & \\
\hline & Total & 200 & & & & \\
\hline \multirow{3}{*}{ Somatic Anxiety } & Male & 150 & 97.40 & 14610.50 & 3285.50 &, 182 \\
\hline & Female & 50 & 109.79 & 5489.50 & & \\
\hline & Total & 200 & & & & \\
\hline \multirow{3}{*}{ Anxiety } & Male & 150 & 101.90 & 15285.50 & 3539.50 &, 542 \\
\hline & Female & 50 & 96.29 & 4814.50 & & \\
\hline & Total & 200 & & & & \\
\hline
\end{tabular}

There were no statistically significant diffe- and anxiety $(, 542)$ sub-scales among the grorences in the cognitive $(, 246)$, somatic $(, 182)$ ups according to gender variable in Table 2.

Table 3. Kruskal Wallis Test Results According to Age Variable

\begin{tabular}{|c|c|c|c|c|c|}
\hline AGE & & $\mathrm{N}$ & sd & $x^{2}$ & $\mathrm{P}$ \\
\hline \multirow{4}{*}{ Cognitive Processes } & 15 years & 100 & 107.49 & & \\
\hline & 16 years & 51 & 103.44 & 6.18 &, 045 \\
\hline & 17 years & 49 & 83.18 & & \\
\hline & Total & 200 & & & \\
\hline \multirow{4}{*}{ Somatic Anxiety } & 15 years & 100 & 113.00 & & \\
\hline & 16 years & 51 & 91.31 & 10.01 &, 007 \\
\hline & 17 years & 49 & 84.56 & & \\
\hline & Total & 200 & & & \\
\hline \multirow{4}{*}{ Anxiety } & 15 years & 100 & 110.22 & & \\
\hline & 16 years & 51 & 103.64 & 11.35 &, 003 \\
\hline & 17 years & 49 & 77.40 & & \\
\hline & Total & 200 & & & \\
\hline
\end{tabular}




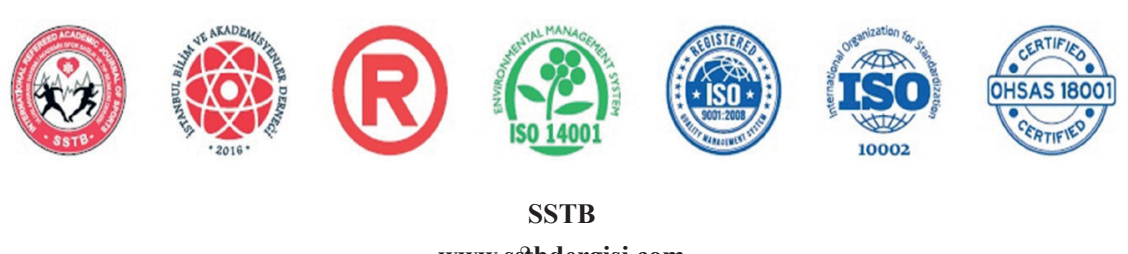

www.sstbdergisi.com

International Refereed Academic Journal of Sports, Health and Medical Sciences

January - February - March Issue 22 Winter Season Year: 2017

GEL CODE: I21-I129-M12- ID:329 K:327

ISSN Print: 2146-8508 Online 2147-1711

(ISO 18001-OH-0090-13001706 / ISO 14001-EM-0090-13001706 / ISO 9001-QM-0090-13001706 / ISO 10002-CM-0090-13001706) (TRADEMARK)

(2015/04315- 2015-GE-18972)

According to the age variable in Table 3, significant differences were found in the subscales of Cognitive (, 045), Somatic (, 007) and Anxiety (, 003) among different age groups. It has been found that the average age of 15 -year-old is the highest. It has been also found that there is a strong positive correlation between sub-dimensions.

\section{DISCUSSION and CONCLUSION}

In this study, the anxiety levels of high school students in physical education classes were investigated. While there was no significant difference between the genders, it has been found that there were significant differences between the age groups. It can be said that there is a significant difference in cognitive, somatic, anxiety sub-dimensions between 15 and 17 years age group and between 16 and 17 age groups in anxiety sub-dimension.

It has been found as a result that according to age 15 and 17 years old, students have difficulty in keeping and focusing on the movements in the physical education classes and they have also difficulty in physical problems (respiratory difficulty etc.), and therefore they worry due to the negative thoughts in physical education classes. This may be due to the adaptation problem in the early years of the study. According to 16 and 17 years old, the worries about fear of making mistakes in physical education classes are high. This may be due to the grade / average event, or the teacher factor. 17 years old student may be in the comfort of graduation. The cause of anxiety can be learned in later studies with a qualitative study.

Noyes observed that students' anxieties increased when their performances were not at the desired level (Artok, 1994). The individual is anxious at all ages, but the reason for the loss of life in every age is different. While the individual is worrying about leaving from the mother in the first years of the life, he worries about getting a friend during the primary school period, in adolescence he has concerns about belonging to a group, having a bad appearance and failing. The top years of anxiety are the first two years of life and adolescence (Alisinanoğlu and Ulutaş, 2000: 65-72). From the literature findings, it can be said that the research group affected the results of being in adolescence period. In the Özgül's (2003), "State and Trait Anxiety Levels in Physical Education and Sport Students", while there was no difference between the state anxiety scores according to gender, trait Anxiety scores were found significantly higher in girls. As a result of Koç's (2004) research, it has been found that "Professional footballers are less affected by the factors that affect their state anxiety levels and their emotions are dominant as their age increases". Erbaş (2005) has examined the 


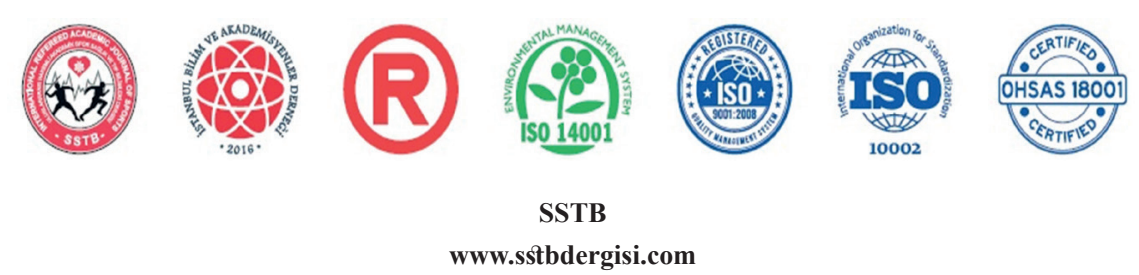

International Refereed Academic Journal of Sports, Health and Medical Sciences

January - February - March Issue 22 Winter Season Year: 2017

GEL CODE: I21-I129-M12- ID:329 K:327

ISSN Print: 2146-8508 Online 2147-1711

(ISO 18001-OH-0090-13001706 / ISO 14001-EM-0090-13001706 / ISO 9001-QM-0090-13001706 / ISO 10002-CM-0090-13001706) (TRADEMARK)

(2015/04315- 2015-GE-18972)

KARATAŞ, Ö., YÜCEL, A S., KARATAŞ, E.Ö., (2016). Basketbol Sporcuların Risk Değerlendirme Düzeylerinin İncelenmesi İnternational Refereed Academic Journal of Sports,21: 109-118

KARTOPU, S., (2012). Lise Öğrenci ve Öğretmenlerinin Durumluk ve Sürekli Kayg1 Düzeylerinin Bazı Değişkenler Açısından İncelenmesi (Kahramanmaraş Örneği). İlahiyat Fakültesi Dergisi, 17(2): 147-170

KAYA, M., VAROL, T., (2004). İlahiyat Fakültesi Öğrencilerinin Durumluk-

Sürekli Kaygı Düzeyleri ve Kaygı Nedenleri (Samsun Örneği). Ondokuz May1s Üniversitesi İlahiyat Fakültesi Dergisi, 17: 31-63

KOÇ, H., (2004). Profesyonel Futbolcularda Durumluk Kaygı Düzeylerini Etkileyen Faktörlerin Değerlendirilmesi. Yüksek Lisans Tezi, Dumlupınar Üniversitesi Sosyal Bilimler Enstitüsü, Kütahya

MARTENS, R., VEALEY, R., BUR TON, D., (1990). Competitive Anxiety in Sport. Champaign, IL: Human Kinetics

ÖNER, N., LECOMPTE, A., (1998). Durumluluk-Süreklilik Kaygı Envanteri El Kitabı. İstanbul: Boğaziçi Üniversitesi Matbaas1.

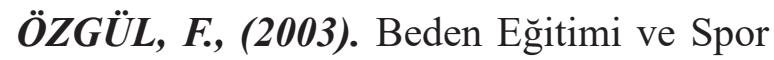
Yüksek Okulu Öğrencilerinde Durumluk ve Sürekli Kaygı Düzeyleri. Yüksek Lisans Tezi, Cumhuriyet Üniversitesi Sağlık Bilimleri Enstitüsü, Sivas

PHILLIPS, D., (1984). The Illusion of Incompetence Among Academically Component Children. Child Development, 55 (6): $2000-2016$

SPIELBERGER, C.D., (1972). Anxiety : Current Trend in Theory and Research. New York: Akademic Press

TEKINDAL, M.A., ERYAŞ, N., TEKINDAL, B., (2010). İlköğretim Okullarındaki Öğrencilerin Sürekli Kayg1 Düzeylerinin Çeşitli Değişkenlere Göre İncelenmesi. Gazi Üniversitesi Endüstriyel Sanatlar Eğitim Fakültesi Dergisi, 26: 79-93

VAROL, K.Y., (2014). Beden Eğitimi Sürekli Kaygı Ölçeğinin Türkçeye Uyarlanması: Geçerlik ve Güvenirlik Çalışması. İnternational Journal of Human Sciences, 11(1)

Author's Note: 3. It has been submitted in the International Sport Sciences, Tourism and Recreation Students Congress as verbal statement (27-29 Mav 2016 Gaziantep). Corresponding Author: Meryem ALTUN, Ömer Halisdemir University, School of Physical Education and Sports Niüde/Türkive (mrymltn@ hotmail.com/05534514538).221-235 